\title{
ESTUDO DE IMPLEMENTAÇÃO DE ENGENHARIA DE MÉTODOS E PCP EM UMA EMPRESA DE MÓVEIS PLANEJADOS
}

\author{
Congresso Nacional Online de Empreendedorismo, 3ạ edição, de 06/12/2021 a 08/12/2021
} ISBN dos Anais: 978-65-81152-30-7

MASSON; Fabio Junior ${ }^{1}$, SILVA; Pedro Henrique Albres da ${ }^{2}$, OLIVEIRA; Muriel Batista de 3, SILVÉRIO; Adriano Serra 4, LIMA; Amanda Camerini 5

\section{RESUMO}

Os avanços globais tecnológicos estão crescentemente inseridos no dia a dia de diferentes formas e segmentos. No ramo de marcenaria não é diferente, e a cada tempo surgem estudos, máquinas e ferramentas que auxiliam no controle de produção e de planejamento, onde essas são criadas ou renovadas, a fim de potencializar os ganhos da empresa, seja em tempo de serviço, melhorias de produção no chão de fábrica, seja na gestão de recursos que auxiliam no desenvolvimento da empresa. Nessa pesquisa, usou-se as metodologias qualitativas e quantitativas bem como, um estudo bibliográfico, visando analisar qual seria a melhor forma de conseguir agregar e promover a entrega do objetivo proposto. Esses recursos podem ser visualizados de maneira direta ou indireta, mantendo uma base sólida e precisa, com visão em melhorar a qualidade e o processo a sere ntregue para o cliente final. Através disso, também é necessário que as empresas se adequem ao futuro no âmbito de capacitar profissionais com visões tanto analíticas quanto em visões operacionais, para que sejam profissionais que ajudem a empresa de diferentes maneiras. Para desenvolver o estudo, teve-se a ajuda de um programa voltado para marcenarias de móveis planejados, focado em melhorar o processo de corte de chapas de MDF ou madeiras, com a finalidade de aumentar aprodutividade de corte e montagem de móveis e, por outro lado, maximizar recursos para economizar a matéria-prima. Além disso, busca combinar os recursos desse programa de cortes com a operação da fábrica, tendo em vista, que esse programa aumenta as previsões de cada serviço. Para isso, a equipe de gestão e de operação possuem uma missão de conciliar essa ferramenta com questões da gestão de pessoas e áreas presentes na administração e engenharia de produção com estudos que melhoram os processos produtivos de uma empresa, seja em produção, análise de recursos operacionais, controle de estoque, controle de orçamentos e prazos de entrega, entre outros. É possível visualizar todos esses recursos, comparando-os com os antigos moldes da empresa em questões de: tempo de serviço, controle dequalidade, questões ergonômicas, divisões corretas de tarefas, treinamentos, etc.Observa-se os avanços presentes com o uso desse software de corte de chapase percebe-se o pujante avanço da empresa não somente em questões de projetos e qualidade de recursos, mas também em melhorias internas dentro da empresa com a equipe de colaboradores. Por fim, o trabalho foi concluído com sucesso. Apresentaram-se as sistemáticas presentes na análise de PCP em uma 
empresa de móveis planejados, através de um programa de otimização de plano de corte. Com a utilização correta do programa, a empresa aumentou seu faturamento em até aproximadamente $30 \%$, seja em questões de tempo de serviço, seja em questões orçamentarias e de lucro da empresa.

PALAVRAS-CHAVE: Produção, Processo, Sistemas 